\title{
Conservative Economic Nationalism and the National Policy: Rae, Buchanan and Early Canadian Protectionist Thought
}

\author{
Eric Helleiner* \\ Department of Political Science, University of Waterloo, 200 University Ave. West, Waterloo, Ontario, \\ Canada N2L 3G1 \\ *Corresponding author. E-mail: ehelleiner@uwaterloo.ca
}

\begin{abstract}
Two distinct strands of conservative Canadian economic nationalism-associated with the ideas of John Rae and Isaac Buchanan-helped to inform the country's protectionist National Policy of 1879. These strands of nationalism were much less influenced by Listian ideas than was economic nationalist thought in many other countries at this time. This study of their content, intellectual sources and influence contributes empirically and analytically to debates in Canadian political economy and international political economy, while also advancing historical scholarship. The arguments also have some potential contemporary relevance in an age when protectionist economic nationalism is rising in the US and elsewhere.
\end{abstract}

\section{Résumé}

Deux courants distincts du nationalisme économique conservateur canadien - associés aux idées de John Rae et d'Isaac Buchanan - ont contribué à éclairer la politique nationale protectionniste du pays en 1879. Ils étaient beaucoup moins influencés par les idées de Listian que par la pensée économique nationaliste dans beaucoup d'autres pays à cette époque. Cette étude de leur contenu, de leurs sources intellectuelles et de leur influence contribue de façon empirique et analytique aux débats sur l'économie politique canadienne et l'économie politique internationale, tout en faisant progresser la recherche historique. Les arguments ont aussi une certaine pertinence contemporaine potentielle à une époque où le nationalisme économique protectionniste est en hausse aux États-Unis et ailleurs.

Keywords: economic nationalism; protectionism; national policy; john rae; isaac buchanan

When justifying his commitment to heightened trade protectionism, Donald Trump (2016) has invoked a long tradition of American economic nationalist thought dating back to the ideas of Alexander Hamilton. Trump's trade policies have encouraged much debate about whether economic nationalist ideas may now gain more political influence elsewhere. Canadians might assume that such 
a trend in their own country could involve a revival of the "left nationalist" economic thought that flourished during the 1970s (Kellogg, 2015). But some pundits (for example, Walkom, 2018) have also suggested a deeper intellectual precedent for a resurgent Canadian economic nationalism: the ideas associated with the country's protectionist National Policy of $1879 .{ }^{1}$

Who were the Canadian economic nationalist thinkers whose ideas helped to inform the National Policy? What was the specific content of their ideas? And what were their intellectual sources? Contemporary Canadian political economy (CPE) scholarship does not shed much light on these questions. While the Canadian left nationalists of the 1970s have been widely studied, prominent CPE textbooks and even detailed surveys of CPE thought in recent decades do not analyze Canadian political economists from the nineteenth century, let alone economic nationalist ones. The discussion of the intellectual history of CPE usually begins, instead, in the interwar years, with a focus on thinkers such as Harold Innis (see, for example, Drache, 1978; Clement and Williams, 1989; Howlett and Ramesh, 1992; Hurl and Christensen, 2015).

One might hope to find answers from scholars of international political economy (IPE), who have devoted much attention in recent years to the history and significance of economic nationalist thought. Much of this literature has been focused on nineteenth-century thought, particularly on the content and international diffusion of the ideas of German-born protectionist thinker Friedrich List. ${ }^{2}$ List's ideas were becoming influential in many countries across the globe at the very time Canada was introducing its National Policy. But Canada's experience vis-à-vis the international diffusion of Listian thought has received little attention in IPE literature.

In this article, I set out to fill these gaps in CPE and IPE literature, advancing two core arguments. First, I suggest that there were, in fact, two different strands of Canadian economic nationalist thought that were particularly prominent in political circles at the time of the National Policy. Both were associated with thinkers whose political leanings were more conservative than those of the left nationalists of the 1970s. One was John Rae (1796-1872), who put forward a sophisticated "infant-industry" case for using specifically targeted and limited protectionism to cultivate national economic development via innovation and technological change. The other was Isaac Buchanan (1810-1883), who backed wider protectionist policies and was more concerned with fostering a development-friendly macroeconomic environment and broader social and environmental goals. Although it is always difficult to prove the influence of ideas on policy outcomes, I cite evidence to suggest that both of these strands of conservative economic nationalist thought played at least some role in informing the National Policy.

Second, in analyzing the intellectual sources of these ideas, I argue that the Canadian experience was distinctive because of the relatively limited influence of Listian thought on both of these strands of Canadian economic nationalism. Although Rae's ideas were similar in some ways to List's, his critique of free trade was developed largely endogenously in the Canadian context. To the extent that an international diffusion of ideas played a major role in Rae's story, it was of a quite different kind: his ideas became influential in Canada via the writings 
of the English political economist John Stuart Mill. Buchanan drew more heavily on foreign thinkers in developing his thought, but List was not the dominant influence. More important to Buchanan were the ideas of the American economic nationalist Henry Carey, whose thought was quite different from List's.

These arguments contribute to CPE and IPE literature not just by filling an empirical gap in those two bodies of scholarship. For CPE scholars, they also highlight the deeper historical roots of CPE thought in the nineteenth century, as well as the ideological diversity within historical traditions of Canadian economic nationalism. The analysis also sheds new light on some aspects of the National Policy that have long interested CPE scholars, namely its relationship to staples-led growth, its focus on employment goals, its openness to foreign investment, and the views of Canada's commercial elite during that time. For IPE scholars, the arguments challenge conventional narratives about the significance of the international diffusion of Listian thought in this period. They also call attention to overlooked diversity within economic nationalist thought circulating internationally in the nineteenth century as well as to the blurry nature of the boundary between "economic liberalism" and "economic nationalism." I also briefly discuss in the article's conclusion some potential contemporary relevance of the analysis in this new era of Trumpian conservative economic nationalism.

In developing these arguments, I draw upon primary material as well as the work of some historians. Much of the historical literature on the origins of National Policy overlooks the role of economic nationalist thought; as Elsbeth Heaman (2014: 212) puts it: "Historians have identified little philosophy and much pragmatism in the development of the National Policy." But important insights about the role of Rae and Buchanan can be found in some scholarship by both historians of the National Policy and historians of economic thought. Although this article is designed to contribute primarily to CPE and IPE literature, its arguments also seek to advance these historical literatures in three ways. First, the distinctions I draw between the two strands of Canadian economic nationalism are ones that have not been brought out effectively in existing historical scholarship. Second, my analysis calls into question arguments that assign Listian ideas a prominent role in Canadian economic nationalism during this time. Finally, I challenge some existing views about Buchanan's ideas.

\section{Rae's Infant-Industry Protectionism}

Any analysis of the economic nationalist ideas informing the National Policy should begin with the architect of the policy itself: John A. Macdonald. Here, List-centred interpretations of nineteenth-century economic nationalism encounter the problem that Macdonald did not cite List's ideas when justifying the new policy. Instead, he mentioned the ideas of the much less well-known figure of John Rae, as did some other Canadian supporters of higher tariffs at the time (Dominion of Canada, 1876: 490-91; Heaman, 2014: 214; 2017: 139; James, 1965:172; Goodwin, 1961: 52, 57, 126; Neill, 1991: 58). Rae receives little mention in contemporary CPE scholarship or in IPE literature on economic nationalism. Even in historical literature on the National Policy, Rae usually receives little more than a passing mention. Who was this man? 
To answer this question, we can turn to historians of economic thought, who have devoted much more attention to Rae's life and innovative economic ideas (see especially James, 1965; Hamouda et al., 1998). After emigrating from Scotland in 1822 at the age of 26, Rae worked in Upper Canada as a schoolteacher and doctor, first at Williamstown until 1831 and then in Hamilton between 1834 and 1848. (From Hamilton, he would move on to California for several years, then to Hawaii for a twenty-year stay, before spending his final days in New York.) Although educated in medicine before immigrating to Canada, Rae developed some important critiques of Adam Smith's ideas about political economy during his time in Upper Canada. These critiques were outlined in their most comprehensive form in a lengthy book (over 400 pages) published in 1834 under the title Statement of Some New Principles on the Subject of Political Economy, Exposing the Fallacies of the System of Free Trade, and of Some Other Doctrines Maintained in the "Wealth of Nations."

Although Rae's book covered many issues, I am interested here in his critique of Smith's support for free trade. At the core of this critique was the argument that Smith had overlooked how tariffs could help bolster "national wealth" in poorer countries (Rae, [1834] 1964: 15). While Smith focused on savings and the division of labour as key sources of economic growth, Rae pointed to the importance of invention and technological change that could raise the productivity of capital and thus "effect an increase of the productive powers of the community" (70). Rae suggested that public authorities had an important role to play in encouraging both innovation at home and the transfer of technologies from abroad, through the introduction of temporary tariffs. The case for public authorities to intervene in markets in this way stemmed partly from the fact that these were costly and risky tasks for individuals to assume on their own. Even more important was Rae's argument that "Individual and National Interests are not Identical" (xv). The benefits derived from technological change lasted much longer than one individual's life; they were, in Rae's words, "continuous with the national existence" (62).

While he supported infant-industry protection, Rae insisted that tariffs be introduced only temporarily and in very specific circumstances that met his goals (including tariffs on luxuries, because they would provide revenue and prevent wasteful spending). He also noted the benefits of free trade where national competitive advantages were based on natural endowments. At the same time, he was strongly critical of free trade advocates who overstated the natural basis of the international division of labour: "Who can positively say what fifty years hence will be the productions of any country?" (Rae, [1834] 1964: 258).

These arguments in support of infant-industry protectionism bore some similarities to arguments made by List. Also similar was Rae's goal of developing an economic policy that would prioritize the "National Interest." Indeed, he went out of his way to highlight that the promotion of national wealth and capital was needed not just for "internal prosperity" but also as a "means of repelling external agressions" (Rae, [1834] 1964: vii). At the same time, however, Rae's economic nationalism co-existed with a conservative political commitment to defending the Canadian colonies' ties to the British crown and empire. The conservative nature of his politics was also evident in his strong disapproval of revolutionary politics 
and his participation in a militia to fight against the 1837 rebellion (James, 1965: 34, $66,133-39,261)$. His writings also embraced Eurocentric settler colonial worldviews: "The large extent of the knowledge of the civilized man, compared with that of savage or barbarian, gives him the power of constructing a much greater number of instruments out of the same materials, and enables the European emigrant to convert the soil and forests of America or New Holland, into means of producing a great mass of desirable events, which it was beyond the capacity of the ignorant native to effect" (Rae, [1834] 1964: 99).

\section{Intellectual sources of Rae's ideas and their influence}

Although many of Rae's economic arguments were similar to List's, Rae made no reference to List in his work and I have seen no evidence that he was influenced by him. Indeed, List's best-known and most influential book, The National System of Political Economy, was not published until 1841, seven years after Rae's work had already appeared. To be sure, List did publish an earlier work in 1827 titled Outlines of American Political Economy. But Rae had already put forward the broad outlines of his case for infant-industry protectionism in an 1825 article (James, 1965: 195206). Moreover, Rae's New Principles was a much more substantial analysis than List's 1827 publication, which was no more than a compilation of short letters he had written in support of the protectionist cause in the United States (where he lived between 1825 and 1832).

Although there is no evidence of any Listian impact on Rae, he was clearly aware of Alexander Hamilton's 1791 Report on Manufactures that supported infantindustry tariffs. But Rae cited Hamilton only briefly in his 1834 book and just in reference to Hamilton's ideas about technological change, not his defense of protectionism (Rae, [1834] 1964: 365-66). Rae's case for tariffs was also much more detailed and sophisticated than Hamilton's shorter report. The references in Rae's ([1834] 1964: 389-91) book also highlight that he was familiar with earlier European mercantilist writings and may also have been influenced by protectionist debates in France where James (1965: 13) notes he spent some brief time before emigrating to Canada.

Scholars who have studied Rae's thought highlight how his ideas derived not primarily from foreign influence but from his practical experience and from observations that arose from living in what he called the "Canadian backwoods" (Rae, [1834] 1964: viii; see also James, 1965: 30, 146, 154-55, 188; Dimand, 1998: 181-82; Hamouda et al., 1998: 4). Before immigrating to Canada, Rae had already shown a strong interest in technology, but it was the stark differences in levels of economic development between Britain and colonial Canada that encouraged his interest in analyzing the significance of innovation in cultivating national wealth. Some historians of thought also suggest that Rae's focus on the possibility of selfsustaining, technologically driven growth drew inspiration from the character of the Upper Canadian economy at the time that he was writing (Neill, 1991: 58, 65). It is also noteworthy that his social circle in Williamstown included merchants who were, in the words of James (1965: 136), "eager to promote the economic growth and the population of Upper Canada." 
The importance of the Canadian context to Rae's thought was also evident from his 1834 book. Although the work had a general focus, it included many Canadian examples. Indeed, Rae initially intended his book to be part of a larger book he planned-but never published-on "Outlines of the Natural History and Statistics of Canada” (James, 1965: 69-72, 139-40). Rae's deep interest in learning from his local economic context also reflected his strong philosophical commitmentinspired by Francis Bacon's ideas-to inductive knowledge (James, 1965: 136).

The originality and importance of Rae's arguments have been recognized by many historians of economic thought, including Joseph Spengler (1959: 393), who suggested that Rae was "possibly as brilliant an economist as nineteenth century North America was to produce." Given the predominantly Canadian origins and focus of Rae's thought, he deserves more recognition from contemporary CPE scholars as a pioneer of their field. His relevance to the CPE field is only reinforced by the fact that he was centrally concerned with an issue that has preoccupied much CPE scholarship: the drawbacks of staples-led growth in the Canadian context. Speaking directly to this issue, Rae advanced the first serious theoretical rationale for cultivating a more internally driven model of Canadian growth based on industrial development.

Macdonald's invocation of Rae to justify the National Policy provides yet one more reason for $\mathrm{CPE}$ scholarship to devote more attention to his ideas. Prominent CPE scholars, such as R. T. Naylor (1997), have been critical of the National Policy, arguing that it did little to challenge a staples-led development model. The fact that Rae-who backed industrial growth-was cited by the National Policy's main architect raises questions about that interpretation, at least as it relates to the initial goals of the policy.

Rae's thought also deserves a more prominent place in IPE scholarship on economic nationalism because it challenges conventional narratives about the nineteenth-century international diffusion of Listian thought. As we have seen, Rae's sophisticated ideas about infant-industry protectionism predated List's much-referenced 1841 book and were heavily influenced by his Canadian context. At the same time, however, there was an important way in which the international diffusion of ideas was significant to the influence of Rae's ideas on Canadian economic nationalism. It concerns how Rae's ideas came to have influence in Canadian political circles at the time of the National Policy. Interestingly, this story also defies the List-focused narrative.

Rae's 1834 book did not initially generate much interest in Canada (or abroad), a result that greatly disappointed the author, who ceased writing about political economy issues (James, 1965: 175). Not until the famous English political economist John Stuart Mill received a copy of Rae's book in 1847 from his colleague Nassau Senior (who recognized its intellectual significance) did the situation begin to change. Despite his commitment to economic liberalism, Mill was impressed by Rae's work and praised it in his widely read Principles of Political Economy. The praise included a passage in which Mill accepted the case for infant-industry protectionism based on Rae's arguments (James, 1965: 167-69; Neill, 1991: 57; Dimand, 1998: 18). For IPE scholars who draw a sharp distinction between the schools of nineteenth-century "economic liberalism" and "economic nationalism," Mill's writing on this point should give some pause. It provides an 
important reminder that the boundary between these positions was often less clear (Harlen, 1999).

Because of the authority of Mill's work in Canadian intellectual circles at the time, his endorsement of Rae's ideas raised their Canadian profile. Macdonald himself invoked Rae's ideas through this roundabout channel in his first major speech committing to what became the National Policy in the House of Commons in 1876. In this speech, Macdonald placed Mill's defense of infant-industry protectionism at the core of his case for higher tariffs, quoting it at length, including the passage that mentioned Rae (Dominion of Canada, 1876: 490-91). For this reason, Neill (1991: 65) suggests that Rae's ideas can be seen as "the intellectual foundation of the National Policy of economic development" (see also Goodwin, 1961: 57). Neill's statement downplays the influence of a second strand of economic nationalist thought analyzed in the next section of this article, but it is true that Mill and Rae were the only political economy thinkers explicitly invoked by Macdonald in this important speech. The process by which Rae's ideas had been roundtripped from Canada and back via Mill highlights a quite different mechanism by which economic nationalist thought diffused internationally than the one depicted in conventional List-centred accounts.

\section{Buchanan's version of economic nationalism}

Rae was not the only Canadian thinker whose defense of protectionism was politically prominent in the years leading up to the National Policy. There were others in both English- and French-speaking parts of the country whose arguments helped to build support (see, for example, Neill, 1991; Goodwin, 1961: ch.2; den Otter, 1982). In this section, I focus on Isaac Buchanan because he is cited by many historians as the leading and most vocal figure in the Canadian protectionist movement, going back as far as the 1850s (see, for example, Bliss, 1987: 247; den Otter, 1982: 164; Forster, 1986: 32, 36; Goodwin, 1961: 49; Kealey, 1980: 10-11, 126, 155-57, 161; Palmer, 1979: 101).

Like Rae, Buchanan emigrated from Scotland. He arrived in Montreal in 1830 at the age of 19, settling initially in Toronto, and then, after 1844, lived primarily in Hamilton. He became one of the leading Canadian import-export merchants and was involved in business ventures such as railway promotion, as well as in politics (McCalla, 1979, 1982). Although Buchanan's protectionist views have received little attention in contemporary CPE and IPE scholarship, he spoke and wrote extensively about political economy in the context of his crusade for higher Canadian tariffs. Many of his speeches and writings were published in 1864 in a book titled The Relations of the Industry of Canada, with the Mother Country and the United States.

Historians have devoted more attention to Buchanan's economic thought, but the most detailed accounts have still lamented the lack of adequate attention to the topic and called for more analysis (Kealey, 1980: 340n28, 377n9; Palmer, 1979: 100; for other discussions, see Forster, 1986: 32, 36-8; Goodwin, 1961: 4951; Henley, 1989: 110-11; Neill, 1991: 78-82; Zeller, 1982). At the same time, there also appears to be skepticism among some historians about prioritizing this research task. McCalla (1982), for example, suggests that Buchanan's arguments "were distinguished more for repetition and forceful language than for political 
insight, analytic rigour, thoroughness, or subtlety" (see also den Otter, 1982: 164; Forster, 1986: 216n29). It is certainly true that Buchanan's writings did not have the same thoroughness, sophistication and clarity as those of Rae. In this section, however, I argue that Buchanan's ideas deserve greater attention. One reason is that some misunderstandings have arisen in the limited historical scholarship on the topic. Another is that Buchanan developed arguments for trade protectionism that were different from Rae's, revealing a distinct strand of Canadian economic nationalist thought that sheds new light on CPE debates about the National Policy as well as on IPE understandings of nineteenth-century economic nationalist thought.

Buchanan described his approach to the study of economic issues as "Patriotic or Social Economy," with a central focus on the "EMPLOYMENT OF OUR OWN PEOPLE" (Buchanan, 1864: 33). He distinguished this approach from the kind of liberal "Political Economy" that was emanating from Britain at the time (229). He argued that while "social economists" represented "labour-power" and consisted of "practical men, or patriots" who took the circumstances of their society into account when developing legislation, liberal political economy represented "moneypower" and consisted of "cosmopolitan theorists" who "legislate for the world" and "view political science as a system of pure mathematics, or, at best, one for the creation of wealth, without any regard for its distribution" (445). Buchanan's insistence on the need to take a wider view than a focus on the creation of wealth was also apparent in his approving quotation of Senior's comment that the art of government "involved the consideration of motives, of which the desire of wealth is only one among many, and aims at objects to which the possession of wealth is only a subservient means" (quoted in Buchanan, 1864: 129).

In developing this approach, Buchanan gained a reputation as a friend of Canadian labour, displaying what Palmer (1979: 102) calls an "unqualified support for the workingman." At the same time, he was no socialist or Marxist. As the compiler of his writings and speeches noted, "Buchanan has always been an efficient opponent of communisms, organizations of labour, and all the silly 'isms' which would make it appear that there is a distinction between the interest of fixed property and labour" (Morgan, 1864: 448). Informed by what McCalla (1982) calls "a conservative outlook on society," Buchanan promoted a nationalist vision involving a kind of organic unity between the interests of Canadian farmers, manufacturers and workers. His nationalism also involved expressions of loyalty to the British empire as well as opposition to "the setting up, as in England, of a separate commercial interest, composed as Manchester is, of German Jews and others, whose only interest is in the prosperity of other countries" (Buchanan, 1864: 185).

Given the emphasis that Buchanan placed on employment, it is not surprising to find this issue prominent in his defense of trade protectionism. He argued that in the face of British competition, higher tariffs would help build up local manufacturing in ways that provided employment for those "unfit for AGRICULTURALISTS," as well as those in the agricultural sector not fully employed throughout the year (Buchanan, 1864: 233). He also argued that protectionist policies would boost local employment indirectly by reducing excessive imports that generated trade deficits, the accumulation of external debt, and a drain of money from the country. He argued that rising debt and tight monetary conditions left Canada exposed to financial crises and 
higher local interest rates, both of which generated unemployment (13). He also argued that protectionist policies would not just generate revenue to pay down external debts but also create less restrictive domestic monetary conditions as Canadians were discouraged from exporting money as a result of their "over-importing from Sheffield, Birmingham, Manchester, Leeds, and Glasgow" (88; see also 38).

Buchanan noted that the growth of local manufacturing would provide new domestic markets for local farmers. As this growing domestic market for their products generated rising incomes for farmers, the local manufacturing sector would, in turn, experience a growing domestic market for its products. In this way, Buchanan argued that protectionism would generate a kind of virtuous cycle of self-sustaining growth involving expanding employment in the mutually dependent domestic agricultural and manufacturing sectors. As he put it, production and consumption "would act and react reciprocally and constantly on each other, so that supply and demand would never fail... . scarcity and gluts would be unknown" (Buchanan, 1864: 98). The dependence on the vagaries of external demand would also be reduced by this development strategy focused on domestic demand. In addition, the strategy would lower transportation costs for all businesses.

Goodwin (1961: 50) suggests that Buchanan "never stressed the importance of tariffs for national development" and was focused instead more narrowly on employment goals. Den Otter (1982: 164) also suggests that "Buchanan failed to develop a broad and coherent development policy." These judgments unfairly downplay the developmental orientation of Buchanan's thought. Like Rae, Buchanan embraced the idea that industrial growth was key to the country's longterm economic development. He quoted approvingly the US economic nationalist Henry Carey's words that manufacturers "cause the growth of capital - facilitating as they do, the development of the powers of MAN" (quoted in Buchanan, 1864: 74). As noted above, he also saw the growth of manufacturing as part of a balanced and broad-based development strategy that included a strong commitment to agricultural prosperity and improvement and to the development of the country's "unrivalled national resources of soil, forest, and minerals" (Buchanan, 1879). While Rae was centrally focused on the role of technological change and innovation in driving long-term growth, Buchanan was more interested in fostering a macroeconomic environment that would be conducive for economic development. ${ }^{3}$

Buchanan combined this broad developmental vision with a much stronger focus on social issues than can be found in Rae's writings. This focus was evident not just in his interest in employment and labour issues but also in the concerns he expressed about the relationship between free trade and inequality. Buchanan cited work suggesting that poverty was growing in agricultural communities that traded with England, as large traders increased profits at the expense of these communities. He argued that the experience of countries such as Ireland in this respect served as an important warning for Canada (Buchanan, 1864: 83). He also cautioned Canadians that countries embracing free trade, such as Mexico, had "fallen under the trader's power" (78). Even in England itself, Buchanan noted how the poor were being squeezed under the regime of free trade, resulting in "pictures of vice, crime, and degradation, not to be exceeded in the world" (79).

Buchanan also advanced a quite modern-sounding environmental critique of free trade, arguing that this policy had encouraged Lower Canada to grow only 
wheat for export in ways that exhausted local soils: "She grew and grew wheat till she could grow no more. The land, like an impoverished animal, became prey of insects" (Buchanan, 1864: 230). One of the benefits of building up a local market for farmers' produce, he argued, was that it would enable a healthier rotation of crops (14-15). He lamented the lack of attention to the environmental costs of a staples-exporting economy: "The argument against Free Trade, or a system of exporting the raw materials of a country, which is to be found in the exhaustion of her soil, has not been paid sufficient attention to ... We are accustomed to take too little account of what is due to the earth" (75n).

Buchanan's case for trade protectionism was thus more wide-ranging than that of Rae. He was also not nearly as concerned as Rae to specify that tariffs should be introduced only in a temporary way in very specific circumstances. To be sure, he did note at one place in his 1864 book that he supported the implementation of protectionist policies for 10 years during the "infancy" of Canadian manufacturers (Buchanan, 1864: 233). But he also described this proposal as a "compromise" advanced by free traders, and he did not return to this point elsewhere in the volume. Indeed, in another place, he made a quite different point: "What we want in Canada ... is a feeling of permanency - a feeling of certainty that our tariff will prove permanent" (38n).

Although Buchanan's support for protectionist measures was much less cautious than Rae's, he was no advocate of autarchy (Buchanan 1864: 132). He was not even dogmatically opposed to free trade. While he warned of Ireland's experience of "free trade with a rich manufacturing country," Buchanan approved of the US-Canada Reciprocity Treaty of $1854-66$ (which focused on primary products) because it enabled Canadian farmers to boost exports to the US market at a time when they were suddenly facing new competition in the British market after the abolition of the Corn Laws (121). He even proposed that the arrangement might be extended to a common market between the two countries-what he called an "American Zollverein"-in order to "get for Canada a greatly extended market for her manufacturers" (45).

Because of this proposal, Naylor (1997: 29) suggests that Buchanan advanced a "rather curious genus" of protectionism: "Buchanan's policy for 'protecting' and building up manufacturing industry in Canada called for free trade in final products with the United States!" But as Naylor acknowledges, there was an important logic behind the idea: Buchanan argued that such an arrangement would encourage British manufacturers to establish operations in Canada to sell to the US market, thereby "decentralizing the manufacturers of the Empire" (Buchanan, 1864: 513; see also 19-20). Buchanan also recommended this policy as only a temporary one, until the Canadian domestic market could be built up: "As our home market increases through the enlargement of our cities and towns, we shall be more independent of the market of the United States" (20-21). When it became clear that the Reciprocity Treaty would end in 1866, he quickly became an advocate of Confederation to create a wider market for all Canadian producers (Kealey, 1980: 13). Even before this moment (and at the same time that he backed the Zollverein idea), he trumpeted the following motto: "A Home Market for the Farmer, Our Best Reciprocity” (Buchanan, 1860; see also 1864: 42). 


\section{Intellectual sources of Buchanan's ideas and their influence}

Because of the differences between his ideas and Rae's, it is not surprising that Buchanan made no reference to the latter. Who, then, were the intellectual sources of Buchanan's distinctive strand of economic nationalist thought? Some historians (for example, Henley, 1989) have linked Buchanan's thought with List's economic nationalist vision. Buchanan did, indeed, describe the German thinker at one point in his 1864 book as "the great Economist” (Buchanan, 1864: 88), citing List's argument that free trade policies in countries such as Russia and the US had been associated with the ruin of local manufacturers as well as with excessive imports and associated outflows of money, financial crises and the accumulation of debt to Britain (Buchanan, 1864: 88-91). Interestingly, however, these are the only references to List's thought in Buchanan's long 1864 book. Much more extensive were his references to other protectionist thinkers, particularly Henry Carey from the United States. 4

While Henley and other historians (for example, Forster, 1986; Neill, 1991; Zeller, 1982) have noted Carey's influence on Buchanan, the distinctiveness of Carey's thought deserves more attention. Like List, Carey criticized English free trade ideology for preventing other countries from building up local manufacturing that could contribute to a more productive economy, reduce trade deficits, offer more diverse employment opportunities and reduce external vulnerability. While List was centrally concerned with the goal of boosting the productive powers of these countries, Carey also had broader social concerns. He worried that England's free trade system had unleashed competitive pressures that were undermining wages, job security and working conditions for the poor in all countries, including England itself. He also wrote about the poor's growing vulnerability to an increasingly wealthy and powerful group of traders in England and elsewhere who sought to monopolize markets and to squeeze producers and consumers across the world. Carey also raised environmental concerns, arguing that monocrop exporting was generating soil exhaustion in agricultural countries around the world.

Buchanan picked up these broader themes in Carey's work, often invoking the latter's arguments explicitly. Buchanan's willingness to endorse wider protectionism than Rae also brought him much closer to Carey's approach than List's. Despite his reputation as a leading protectionist, List endorsed tariffs only in very restrictive circumstances: to cultivate infant industries and only in countries with a "temperate climate" and that had "advanced" agriculture and "a high degree of civilization and political development” (List, [1841] 1885: 212, 115). Even then, List ([1841] 1885: 179) argued that these tariffs should initially be "very moderate [and] only rise gradually" and then be removed as soon as the industry was able to face foreign competition. By contrast, Carey's support for protectionism was more fulsome and came with fewer caveats. Carey (1858: ch. 2) also combined protectionism with a proposal-absent from List's work-to decentralize manufacturing domestically via the creation of multiple industrial clusters across the territory of a country. ${ }^{5}$

Although Carey's ideas were the central influence on Buchanan's thinking, Buchanan also cited some other writers who made similar arguments, such as Britain's John Barnard Byles and America's Henry Clay, E. Peshine Smith and 
especially Horace Greeley (Buchanan, 1864: 30, 40-41, 74, 128). These protectionist thinkers focused on many of the same broader issues that interested Carey and Buchanan, often citing and influencing each other in ways that represented an alternative international network of protectionist thinkers, separate from the network associated with Listian thought. This network and its intellectual distinctiveness has received little attention from either historians or IPE scholars interested in nineteenth-century economic nationalist thought.

Because Buchanan drew heavily on these thinkers, his ideas do not have the same innovative quality as Rae's. At the same time, his thought was not entirely derivative. In addition to placing greater emphasis on some of the points raised by these foreign thinkers, he adapted their arguments to the Canadian contexta context which had received inadequate attention. Buchanan also advanced some distinct policy recommendations, such as his temporary support for the US-Canada Reciprocity Treaty (which Carey opposed).

Goodwin (1961: 50) notes how Buchanan, in his old age, "liked to be called 'the father of the National Policy."' Goodwin himself, however, is skeptical of Buchanan's influence on Canadian trade policy during that time (see also McCalla, 1982; den Otter, 1982: 164n47). Although Buchanan's claim was certainly overstated, there are good reasons to think that Buchanan did have some influence on the origins of the National Policy. In addition to his long-standing role of mobilizing political support for higher tariffs, Buchanan had a friendly relationship with Macdonald, who had long expressed interest in Buchanan's protectionist views. For example, at an event chaired by Buchanan in Hamilton as far back as 1860, Macdonald had noted Buchanan's interest in "questions of political economy" and praised how tariffs would "encourage manufacturing" in ways that would "raise up a home market, and give a double market to the farmer and labourer" as well as make the population less "dependent" on foreign markets (quoted in Pope, 1930: 221). According to Gwyn's (2011: 278-79) recent biography, Macdonald also began after Confederation to make "determined attempts to master the subject [of political economy]," a process in which he "got a lot of information from the Hamilton businessman Isaac Buchanan." Lockhart (1939: 132) also points to Buchanan's role in helping to improve Macdonald's knowledge on the topic in the 1870s. In addition, some historians have noted how Buchanan's ideas were circulating prominently in Conservative party circles at the time among supporters of the National Policy (Henley, 1989: 111; Kealey, 1980: 11).

In his important 1876 speech committing to higher tariffs (which included the reference to Rae), Macdonald also invoked ideas that resonated with those of Buchanan (although some of these themes could also be found in Rae's and List's writings). For example, Macdonald noted that "it is the interest of the agriculturalist to have a certain market at his own door" and that the agricultural community should not "be forced to look to a foreign market altogether for the sources of their prosperity and for their purchasers." He added that protection would encourage manufacturing that would, in turn, provide employment for those who did not want to, or could not, work in agriculture: "all men are not to be farmers." In addition, Macdonald saw tariffs as protection against foreign merchants using Canada as a "slaughter market" in which to dump excess products or seeking to gain power over local markets by sending goods "into this country for the purpose of bringing 
down prices here, injuring our manufacturers, and driving them out of the market and afterwards getting control of the market" (Dominion of Canada, 1876: 49293). More generally, Macdonald also noted the importance of values beyond simply the accumulation of wealth: "The great Political Economists ... have always held that there are other things as important, and more important to a nation, than the mere aggregation of wealth" (Dominion of Canada, 1876: 490).

The ideas of foreign thinkers who had influenced Buchanan-particularly Carey, Byles, and Greeley-were also invoked by other Canadian supporters of higher tariffs at the time (Dominion of Canada, 1876: 80, 136-37; 1878: 158, 1014, 1052, 1056; Goodwin, 1961: 47, 52, 57n46, 69, 200; Hurlbert, 1870; Maclean, 1868: 56-58; Neill, 1991: 48, 83). Combining this fact with the evidence of Buchanan's influence, it seems fair to suggest that support for the National Policy was informed not just by the kinds of infant-industry arguments of Rae but also by the broader case for protectionism supported by Buchanan, Carey and these other thinkers.

Recognizing the influence of this distinct strand of economic nationalism sheds new light on some CPE debates about the National Policy. To begin with, some CPE scholars have been critical of the policy's architects for focusing more on goals such as employment than on the long-term building up of strong Canadian-owned industry. They have offered various explanations for this focus, including staples mentalities, class dynamics and the absence of threats to Canada's security (see, for example, Laxer, 1989; Naylor, 1997). The attitude of policy makers may also, however, have been a product the ideational environment of time: employment was a central concern for the socially oriented economic nationalists of the Buchanan school.

Buchanan's ideas can also help to explain another issue that has interested CPE scholars: the lack of concern about foreign ownership in manufacturing during that time (see, for example, Laxer, 1989). As we have seen, Buchanan expressed interest in attracting foreign investors to establish industry in Canada. Interestingly, Rae also welcomed the transfer of industrial technology by foreign investors. Given these attitudes, it is not surprising that the growth of branch plants in the $1880 \mathrm{~s}$ and 1890s was, in Bliss's (1970: 31) words, "hailed as one of the finest achievements of the National Policy." Bliss (1970: 32) noted that this dimension of the National Policy looked different from the perspective of the late 1960s when it appeared more as a "peculiarly self-defeating kind of economic nationalism" because its tariff walls had simply encouraged "the enemy to jump over them." But the peculiarity of earlier Canadian economic nationalist thought should not be overstated. While policy makers in some other countries were more cautious about foreign investment (Williams, 1994), even the best known nineteenth-century economic nationalist, Friedrich List (1841 [1885]: 167, 227), wrote that he hoped that infant-industry tariffs would "stimulate foreigners to come over to our side with their productive powers," with the result that "a mass of foreign capital, mental as well as material, is attracted into the country."

Finally, Buchanan's role raises questions about CPE analyses that have been critical of the staples orientation of Canada's "commercial capitalist class" at the time of the National Policy (Naylor, 1997: 286). Because of his deep involvement in the import-export business and railway promotion, Buchanan was a prominent 
member of this class, but we have seen how he was critical of the staples-led growth model. Naylor himself questions the seriousness of this criticism, pointing to his "curious genus" of economic nationalism that included support for free trade with the US. I have already suggested, however, how this support was not as curious as it appeared. ${ }^{6}$ How, then, can we reconcile Buchanan's critique of the staples-led growth with his class position?

Forster (1986: 36-37) suggests that Buchanan's interest in a new development model stemmed partly from concerns about declining profit opportunities as the Upper Canadian farming frontier reached its limits. $\mathrm{He}$ also notes that Buchanan's self-identity reflected more than just his merchant role: his father had been involved in textile manufacturing, and Buchanan also saw himself as a landed gentleman who identified with the protectionist views of British landed gentry.

The "conservative" content of Buchanan's economic nationalism also helps explain his position. Palmer (1979: 102) argues that his economic ideas need to be seen in the context of his desire to "siphon off the discontent capable of mounting a revolutionary working-class upheaval," discontent that had concerned him ever since he fought-like Rae-against the 1837 rebellion. Protectionism could diffuse domestic discontent by providing employment and binding labour and capital together through what Palmer (1979: 98) calls a "national producer ideology." This ideology may also have found particular resonance in his home city of Hamilton, where artisan-led "craft capitalism" remained prominent into the 1870s, encouraging a more optimistic view of industrial capitalism among workers and opportunities for cross-class alliances (Kristofferson, 2007). ${ }^{7}$ There is, in other words, no need to question the seriousness of Buchanan's rejection of the staples model to explain how someone of his class position might come to support protectionism.

\section{Conclusion}

Who were the Canadian economic nationalist thinkers whose ideas helped to inform the National Policy? What was the specific content of their ideas and their intellectual sources? Although it is notoriously challenging to prove the causal impact of ideas on policy, I have argued in this article that there is considerable evidence to suggest that the National Policy was informed at least in part by two different strands of Canadian economic nationalist thought: 1) Rae's targeted infant-industry protectionism, which focused on the role of innovation and technological change in economic development, and 2) the wider developmental protectionism of Buchanan, which had a more macroeconomic focus and included broader social and environmental goals. I have also argued that these two strands of thought were much less influenced by Listian thought than were the types of economic nationalism found in many other countries during this time. In Rae's case, his ideas emerged largely endogenously from his Canadian experience and then became influential in Canada through the unusual international channel of the writings of Mill. While Buchanan did cite List, the much more important influence on his thought was Carey, whose ideas were quite different ideas from those of List.

In addition to filling an empirical gap in CPE scholarship, these arguments encourage CPE scholars who see the origins of their field in the writings of Innis and other 
interwar thinkers to recognize the richness and diversity of Canadian political economic thought in an earlier era. Although neither Rae nor Buchanan was a professional political economist, they spoke directly to themes that became prominent in later CPE scholarship, notably the costs of a staples-based development model. My analysis also highlights the ideological diversity of Canadian economic nationalist thought (see also Nossal, 1985: 67), since Rae and Buchanan are associated with more conservative politics than the better-known left nationalists of the 1970s. The content of both men's ideas also sheds new light on some aspects of the National Policy that have long interested CPE scholars, such as its relationship to a staples-led growth model, policy makers' focus on employment goals and lack of attention to foreign ownership of manufacturing, and the views of the commercial elite.

The analysis also makes three contributions to IPE scholarship on nineteenthcentury economic nationalism, a literature that has devoted scant attention to the Canadian experience. First, although Listian ideas were cited by some Canadian advocates of protectionism in the years leading up to the National Policy, ${ }^{8}$ those ideas did not have the same kind of influence evident in many other countries at this time. The Canadian experience thus highlights the need to recognize the limits of the international influence of Listian ideas as well as the significance of more endogenous sources of protectionist thought (in the case of Rae) and alternative non-Listian international networks of economic nationalist ideas (in the case of Buchanan). Second, differences between the infant-industry protectionism of Rae and List, on the one hand, and the broader protectionist ideas of Buchanan and Carey, on the other, call attention to a diversity within nineteenth-century protectionist economic nationalist thought that has not been well recognized or analyzed within IPE scholarship. Third, the fact that Rae's case for infant-industry protectionism came to prominence in Canada through Mill's writing reinforces Christine Harlen's (1999) important argument that IPE scholars have often drawn too sharp a division between the nineteenth-century schools of "economic liberalism" and "economic nationalism."

In addition to making these contributions to CPE and IPE literature, the article has engaged with the insights of historians in a number of specific ways. These engagements have been detailed in the body of the article, but three broad contributions to this literature can be noted here. The first concerns the differences that I have identified between the two strands of economic nationalist thought informing the National Policy. Existing historical literature focuses on just one of these strands, or combines them in ways that overlook their differences, or underplays the full extent of the differences. The second concerns the way in which my analysis calls into question arguments that assign Listian thought the leading role in the Canadian protectionist movement at the time of the National Policy. For example, in his important analysis of Canadian economic nationalist thought between 1846 and 1885, Henley (1989: 107, 110) argues that it had "international origins," with Canadian thinkers following "Friedrich List in particular." A final contribution has been to deepen understandings of Buchanan's economic thought, a subject that has attracted less attention than Rae's ideas have. My analysis has questioned historical analyses that have been skeptical of the developmental orientation of his ideas, of his commitment to protectionist policies and of the political influence and broader significance of his economic thinking. 
I conclude with a final comment about potential contemporary relevance. As noted in the introduction, Trump's protectionist policies have encouraged debate about the growth of economic nationalist thinking in other countries, including Canada. Although Canadian economic nationalism has been associated with the political left in recent decades, this article highlights how it also has a deeper, more conservative past. What is the likelihood that a resurgent Canadian protectionist movement might echo the more conservative economic nationalist thought of the nineteenth century instead of that of the left nationalists of the 1970s? One factor that could encourage this outcome is the example of Trump's conservative economic nationalism next door. If contemporary Canadian conservatives imported US conservative economic nationalism, they would, in fact, be following a path taken by Buchanan. If they emulated Trump in combining protectionism with a rhetorical commitment to workers, they would also be following in Buchanan's footsteps. Even the Trumpian overtones of ethnic nationalism have some parallels in Buchanan's thought. Gaining a better understanding of the history of early Canadian protectionist thought may help us be better prepared for these possible outcomes in this era of Trumpian economic nationalism.

Acknowledgments. I am very grateful to Heather Whiteside and the anonymous reviewers of this journal for their helpful comments as well as to the Social Sciences and Humanities Research Council of Canada (435-2015-0571) and the Killam Fellowship program for their support of this research.

\section{Notes}

1 Although sometimes infused with wider meaning, the term National Policy is used in this article to refer to the 1879 tariffs. Following Nossal (1985) and more recent literature (Helleiner and Pickel, 2005), economic nationalism is used to refer to an ideology committed to seeing the economy serve nationalist goals. This literature highlights how economic nationalism need not be associated with protectionist policies. Indeed, some free traders in the 1870s cast their arguments in nationalist terms (for example, den Otter, 1997). In this article, however, I focus only on protectionist strands of economic nationalist thought.

2 For a recent contribution to this large literature (which cites earlier work), see Ince, 2016.

3 Rae did note briefly that the growth of manufacturing would create local markets for farmers, reduce transportation costs, and create new employment opportunities, but these points were not at the centre of his analysis (Rae [1834] 1964: 364-7; James 1965: 195).

4 Buchanan also corresponded with Carey in the 1870s (Library and Archives Canada, Manuscript Group 24, D16, vol. 20, pp. 17406-18, 17431-4, 17448-51, 17461-73).

5 This proposal is interesting in light of later criticism that the National Policy centralized manufacturing in central Canada.

6 Naylor also did not mention Buchanan's more radical proposals for an inconvertible currency (proposals that I do not have room to discuss and that did not inform the National Policy) (Helleiner, 2006: 32-36). 7 Craven and Traves (1979) note how cross-class alliances initially supporting the National Policy increasingly unravelled in subsequent decades, as many farmers and workers came to associate it with monopoly power. 8 In addition to Buchanan's mention of List, see Dominion of Canada (1878: 1055), Goodwin (1961: 47-48, 51, 57n46), Neill (1991: 48), and Hurlbert (1870: 9-10).

\section{References}

Bliss, Michael. 1970. “Canadianizing American Business." In Close the 49th Parallel, ed. Ian Lumsden.

Toronto: University of Toronto Press.

Bliss, Michael. 1987. Northern Enterprise. Toronto: McClelland and Stewart.

Buchanan, Isaac. 1860. A Home Market for the Farmer, Our Best Reciprocity. Hamilton: The Spectator. 
Buchanan, Isaac. 1864. The Relations of the Industry of Canada, with the Mother Country and the United States, ed. Henry Morgan. Montreal: John Lovell.

Buchanan, Isaac. 1879. The Philosophy and Practice of Currency Reform. October 28. Library and Archives Canada, Manuscript Group 24, D14, vol.108, file 070979.

Carey, Henry. 1858. Principles of Social Science. Vol. 1. Philadelphia: J. B. Lippincott.

Clement, Wallace and Glen Williams. 1989. "Introduction." In The New Canadian Political Economy, ed. Wallace Clement and Glen Williams. Montreal: McGill-Queen's University Press.

Craven, Paul and Tom Traves. 1979. "The Class Politics of the National Policy, 1872-1933." Journal of Canadian Studies 14 (3): 14-38.

den Otter, Andy. 1982. "Alexander Galt, the 1859 Tariff and Canadian Economic Nationalism." Canadian Historical Review 63 (2): 151-78.

den Otter, Andy. 1997. The Philosophy of Railways. Toronto: University of Toronto Press.

Dimand, Robert. 1998. "Rae and International Trade." In The Economics of John Rae, ed. Omar Hamouda, Colin Lee and Douglas Mair. London: Routledge.

Dominion of Canada. 1876. Debates of the House of Commons of the Dominion of Canada, 3rd Parliament, 3rd Session. Vol. 1. Ottawa: Maclean, Roger.

Dominion of Canada. 1878. Debates of the Senate of the Dominion of Canada, 3rd Parliament, 5th session. Vol. 1. Ottawa: C. W. Mitchell.

Drache, Daniel. 1978. "Rediscovering Canadian Political Economy." In A Practical Guide to Canadian Political Economy, ed. Wallace Clement and Daniel Drache. Toronto: James Lorimer.

Forster, Ben. 1986. A Conjunction of Interests. Toronto: University of Toronto Press.

Goodwin, Craufurd. 1961. Canadian Economic Thought. Durham: Duke University Press.

Gwyn, Richard. 2011. Nation Maker. Toronto: Random House Canada.

Hamouda, Omar, Colin Lee and Douglas Mair. 1998. eds. The Economics of John Rae. London: Routledge.

Harlen, Christine. 1999. "A Reappraisal of Classical Economic Liberalism and Economic Nationalism." International Studies Quarterly 43 (4): 733-44.

Heaman., Elsbeth. 2014. "Macdonald and Fiscal Realpolitik." In MacDonald at 200, ed. Patrice Dutil and Roger Hall Toronto: Dundurn.

Heaman, Elsbeth. 2017. Tax, Order and Good Government. Montreal: McGill-Queen's University Press.

Helleiner, Eric. 2006. Towards North American Monetary Union? Montreal: McGill-Queen's University Press.

Helleiner, Eric and Andreas Pickel, eds. 2005. Economic Nationalism in a Globalizing World. Ithaca: Cornell University Press.

Henley, Kevin. 1989. “The International Roots of Economic Nationalist Ideology in Canada, 1846-1885.” Journal of Canadian Studies 24 (4): 107-21.

Howlett, Michael and Mishra Ramesh. 1992. The Political Economy of Canada. Toronto: McClelland and Stewart.

Hurl, Chris and Benjamin Christensen. 2015. "Building the New Canadian Political Economy." Studies in Political Economy 96 (1): 167-93.

Hurlbert, J. Beaufort. 1870. Field and Factory Side by Side. Montreal: John Lovell.

Ince, Onur. 2016. "Friedrich List and the Imperial Origins of the National Economy." New Political Economy 21 (4): 380-400

James, R. Warren. 1965. John Rae, Political Economist. Vol. 1, Life and Miscellaneous Writings. Toronto: University of Toronto Press.

Kealey, Greg. 1980. Toronto Workers Respond to Industrial Capitalism, 1867-1892. Toronto: University of Toronto Press.

Kellogg, Paul. 2015. Escape from the Staple Trap. Toronto: University of Toronto Press.

Kristofferson, Robert. 2007. Craft Capitalism. Toronto: University of Toronto Press.

Laxer, Gordon. 1989. Open for Business. Toronto: Oxford University Press.

List, Friedrich. [1841] 1885. The National System of Political Economy. Trans. Sampson S. Lloyd. London: Longmans, Green.

Lockhart, A. D. 1939. "The Contribution of Macdonald Conservatism to National Unity, 1854-78." In The Canadian Historical Association: Report of the Annual Meeting Held at Montreal May 25-26, 1939. Toronto: University of Toronto Press. 
McCalla, Douglas. 1979. The Upper Canada Trade, 1834-1872: A Study of the Buchanans' Business. Toronto: University of Toronto Press.

McCalla, Douglas. 1982. "Buchanan, Isaac." In Dictionary of Canadian Biography, vol. 11, University of Toronto/Université Laval, 2003-. http://www.biographi.ca/en/bio/buchanan_isaac_11E.html (April 15, 2018).

Maclean, John. 1868. Protection and Free Trade. Montreal: John Lovell.

Morgan, Henry. 1864. “Appendix VIII. Isaac Buchanan, Esq., M.P.” In Buchanan, 1864.

Naylor, R. T. 1997. The History of Canadian Business: 1867-1914. Rev. ed. Montreal: Black Rose Books.

Neill, Robin. 1991. A History of Canadian Economic Thought. London: Routledge.

Nossal, Kim. 1985. "Economic Nationalism and Continental Integration." In The Politics of Canada's Economic Relationship with the United States, ed. Denis Stairs and Gilbert Winham. Toronto: University of Toronto Press.

Palmer, Bryan. 1979. A Culture in Conflict. Montreal: McGill-Queen's University Press.

Pope, Sir Joseph. 1930. Memoirs of the Right Honourable Sir John Alexander Macdonald. Rev. ed. Toronto: University of Toronto Press.

Rae, John. [1834] 1964. Statement of Some New Principles on the Subject of Political Economy, Exposing the Fallacies of the System of Free Trade, and of Some Other Doctrines Maintained in the "Wealth of Nations." New York: Augustus Kelley.

Spengler, Joseph. 1959. "John Rae on Economic Development." Quarterly Journal of Economics 73 (3): 393-406.

Trump, Donald. 2016. "Declaring American Economic Independence." Speech at Alumisource, Monessen, Pennsylvania, June 28.

Walkom, Thomas. 2018. “Time to Prepare a National Policy for the Post-NAFTA Era.” Toronto Star, June 26.

Williams, Glen. 1994. Not for Export. Toronto: McClelland and Stewart.

Zeller, Suzanne. 1982. "Nationalism as a Function of Utility." Canadian Review of Studies in Nationalism 9 (2): 225-46.

Cite this article: Helleiner E (2019). Conservative Economic Nationalism and the National Policy: Rae, Buchanan and Early Canadian Protectionist Thought. Canadian Journal of Political Science 52, 521-538.

https://doi.org/10.1017/S0008423918001026 